\title{
THE ORIENTAL IN
}

The mechanics of ancient egyptian magical Practice Robert K. Ritner

STUDIES IN ANCIENT ORIENTAL CIVILIZATION, No. 54

To date, no comprehensive treatment of Egyptian magic has focused on the practice of the magician. Both general studies and textual publications have emphasized instead the religious elements in the contents of recited spells, while the accompanying instructions, with their vignettes and lists of materials, instruments, and ritual actions remained uninvestigated. This study represents the first critical examination of such "magical techniques," revealing their widespread appearance and pivotal significance for all

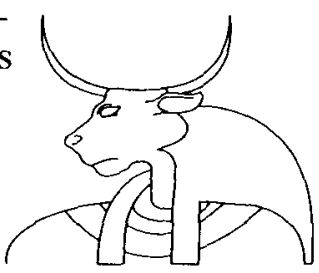
Egyptian "religious" practices from the earliest periods through the Coptic era, influencing as well the Greco-Egyptian magical papyri.

Price $\$ 45.00$

DIRECT YOUR INQUIRIES TO: The Oriental Institute Press

- 1155 East 58th Street • Chicago, IL 60637 - Tel. (312) 702-9508

- Facs. (312) 702-9853 


\section{Index of Authors}

Baldwin, John T. God and the World: William Paley's

Argument from Perfection Tradition-A

Continuing Influence

Bovon, François Studies in Luke-Acts: Retrospect and

Prospect

Breuer, Edward Politics, Tradition, History: Rabbinic Judaism and the Eighteenth-Century Struggle for Civil Equality

Chamberlain, Ava The Theology of Cruelty: A New Look at the Rise of Arminianism in Eighteenth-Century New England

Chandler, Stuart When the World Falls Apart: Methodology for Employing Chaos and Emptiness as Theological Constructs

Chazan, Robert Joseph Kimhi's Sefer Ha-Berit: Pathbreaking Medieval Jewish Apologetics

Clooney, Francis X. Extending the Canon: Some Implications of a Hindu Argument about Scripture

D'Angelo, Mary Rose Theology in Mark and Q: $A b b a$ and "Father" in Context

Georgi, Dieter The Interest in Life of Jesus Theology as a Paradigm for the Social History of Biblical Criticism 
Gibbs, Norman B. "In Our Nature": The Kenotic Christology and Lee W. Gibbs of Charles Chauncy

Jackson, Howard M. The Setting and Sectarian Provenance of the Fragment of the "Celestial Dialogue" Preserved

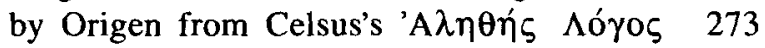

Kugel, James The Story of Dinah in the Testament of Levi 1

LiDonnici, Lynn R. The Images of Artemis Ephesia and GrecoRoman Worship: A Reconsideration

Palmquist, Stephen Kant's "Appropriation" of Lampe's God 85

Perkins, Judith The "Self" as Sufferer 245

Pullapilly, Cyriac K. Agostino Valier and the Conceptual Basis of the Catholic Reformation

Ruprecht, Louis A., Jr. Athenagoras the Christian, Pausanias the Travel Guide, and a Mysterious Corinthian Girl

Scott, Alan Pseudo-Aristotle's Historia Animalium 9 in Origen

Thandeka Schleiermacher's Dialektik: The Discovery of the Self that Kant Lost

Thomas, Owen C. Public Theology and Counter-Public Spheres 453

Ward, Roy Bowen Women in Roman Baths 


\section{New Releases in Biblical Studies from Hendrickson Publishers}

Jesus and the Last Days The Interpretation of the Olivet Discourse

George R. Beasley-Murray Cloth, $\$ 29.95$

What was Jesus' understanding of the last days? Anyone wrestling with this query must brave the tempest of controversy surrounding the interpretation of Mark 13-a passage on which it seems every New Testament scholar of the last century has felt compelled to comment. From Strauss to Schniewind, Perrin to Drewermann, rabbit trails to roadways, Beasley-Murray charts the complex and sometimes confusing paths of interpretation. us plainly where a full range of cognate sources may be found, and how comparative analysis might proceed." James $\mathrm{H}$. Charlesworth of Princeton Theological Seminary adds that Evans's book is "more than a map to terra incognito, it is a helpful companion for all who study Judaism and 'Christianity' before the establishment of the Holy Roman Empire."

\section{Religion and Culture in Ancient Israel}

J. Andrew Dearman

Cloth, \$19.95

"Culture shapes religion; religion shapes culture." Valid for society prehensive, and most useful introduction to Josephus as the key to the background for the New

Testament is Steve Mason's book..."

$$
\begin{aligned}
& \text { - Louise H. Feldman } \\
& \text { Yeshiva University }
\end{aligned}
$$

The Gospel According to Saint Mark

Black's New Testament

Commentary Series

Morna D. Hooker

Cloth, $\$ 24.95$

Joseph A. Fitzmyer of the Catholic University of America praises the work of Cambridge professor Morna Hooker as " $a$ balanced attempt to interpret
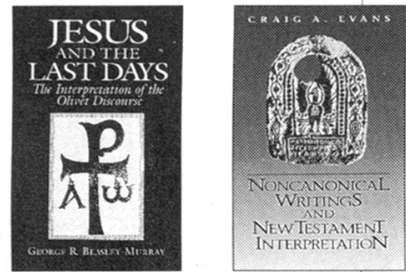

Noncanonical Writings and New Testament

Interpretation

Craig A. Evans

Cloth, \$19.95

Sound New Testament interpretation depends on familiarity with and understanding of ancient primary sources. In what is sure to become a standard resource for students of NT interpretation, Professor Evans pulls together the essentials of date, language, text and translations, and general bibliography.

The Reverend Dr. Bruce Chilton of Bard College comments: "The publication of Professor Evans's book is an event of first importance for advanced students of the New Testament everywhere.... [This book] shows
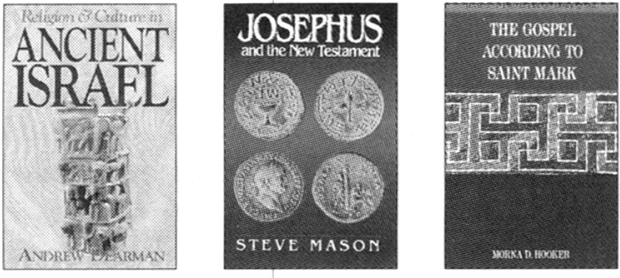

today, this axiom was no less true in the ancient Near Eastern world. In Religion and Culture in Ancient Israel, Dearman explores this dynamic interplay in the religious practices of Israel. For any student of the living religion of Israel and the culture that it shaped (and by which it was shaped), Dearman offers a cogent and thought-provoking inquiry

\section{Josephus and the New} Testament

Steve Mason

Paper, \$9.95

"There can be no doubt that the best aid for understanding the background of the New Testament is its contemporary, Josephus: and there can now be no doubt that the most careful, most com-
Mark 'at every level, 'but primarily from that of 'the evangelist himself'- how he understood the nature of 'the good news about Jesus Christ.'

Hooker's Gospel According to Saint Mark heralds the reappearance of Black's (formerly Harper's) New Testament Commentary in this country. As the first in a series of replacement or revised volumes-includ ing J. D. G. Dunn, Galatians, and C. K. Barrett, Romans [rev.] Mark signals a welcome new standard in New Testament commentaries.

For a complete catalog, call or write:

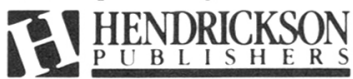

PO. BOX 3473- PEABODY MA 01961-3473 


\title{
CHRISTIANITY AND Modern POLITICS
}

\section{Edited by Louisa S. Hulett}

\author{
1993. ix + 435 pages. \\ ISBN 3-11-013462-4 Cloth $\$ 59.95$ \\ ISBN 3-11-013461-6 Paper \$29.95
}

Interpretations of the extent to which the First Amendment guarantees freedom of religion have long been a source of controversy in the United States. This anthology examines the debate from its origins to the present, tracing the separation of church and state across disciplines and centuries. Contributors include theologians, philosophers, political scientists, sociologists and lawyers, and the result is a kaleidoscope of viewpoints regarding the impact of Christianity on the modern political scene. This unique collection will be of value to both

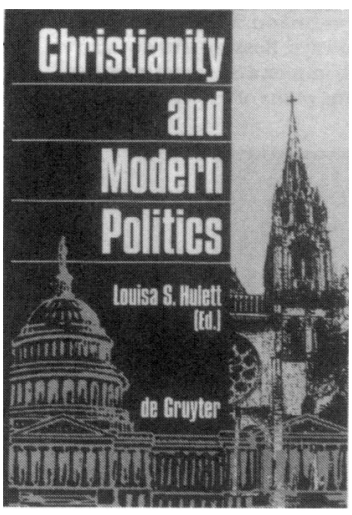
scholars and students interested in the legal, historical or ethical implications of religious freedom as guaranteed by the Constitution.

\section{From the contents:}

Introduction • I. On Christianity, Civil Religion, and Politics • II. The Free Exercise of Religion $\bullet$ III. God and Government: The Establishment Clause • IV. Religion Clauses and Supreme Court Cases $\bullet$ V. Secular Humanism as Religion: The Great Debate • VI. The Rise of Fundamentalism • VII. War, Peace, and Pacifism $\bullet$ VIII. Liberation Theology $\bullet$ Selected Readings

\section{Prices subject to change.}

Walter de Gruyter
Berlin - New York
For North America:

Walter de Gruyter, Inc.

200 Saw Mill River Road

Hawthorne, NY 10532 


\section{Now available in a paperbound student edition}

\section{IrR \\ Theologische Realenzyklopädie Studienausgabe, Part 1}

\section{Volumes 1 (Aaron) - 17 (Katechismuspredigt) and complete index}

In cooperation with Horst Robert Balz, James $K$. Cameron, Wilfried Härle, Stuart G. Hall, Brian L. Hebblethwaite, Richard Hentschke, Wolfgang Janke, Hans-Joachim Klimkeit, Joachim Mehlhausen, Knut Schäferdiek, Henning Schröer, Gottfried Seebaß, Clemens Thoma

Edited by Gerhard Müller

1993. 17 vols. and index vol. Approx. 800 pages per vol. Paperbound \$795.00 ISBN 3-11-013898-0

In 1976, Walter de Gruyter began publishing the Theologische Realenzyklopädie (TRE), an essential reference work on theological research being conducted around the world. We are now pleased to announce the publication of a paperbound Studienausgabe, at a price substantially lower than the hardcover edition. The first 17 volumes are now available. In approximately seven to eight years, the next set of volumes continuing the Studienausgabe will be published. The additional volumes that will complete the set will be offered at a later date.

Price subject to change.

\section{Walter de Gruyter Berlin • New York}

For North America:

Walter de Gruyter, Inc. 200 Saw Mill River Road Hawthorne, NY 10532 


\section{5:4 OCTOBER 1992}

389 The Images of Artemis Ephesia and Greco-Roman

Worship: A Reconsideration

Lynn R. LiDonnici

417 Joseph Kimhi's Sefer Ha-Berit: Pathbreaking Medieval Jewish Apologetics

Robert Chazan

433 Schleiermacher's Dialektik: The Discovery of the Self that Kant Lost

Thandeka

453 Public Theology and Counter-Public Spheres

Owen C. Thomas

467 When the World Falls Apart: Methodology for Employing Chaos and Emptiness as Theological

Constructs

Stuart Chandler

493 Summaries of Doctoral Dissertations

505 Books Received 